\title{
Minerva
}

\section{Science, Politics/Policy and the Cold War in Argentina: From Concepts to Institutional Models in the 1950s and '60s

\author{
--Manuscript Draft--
}

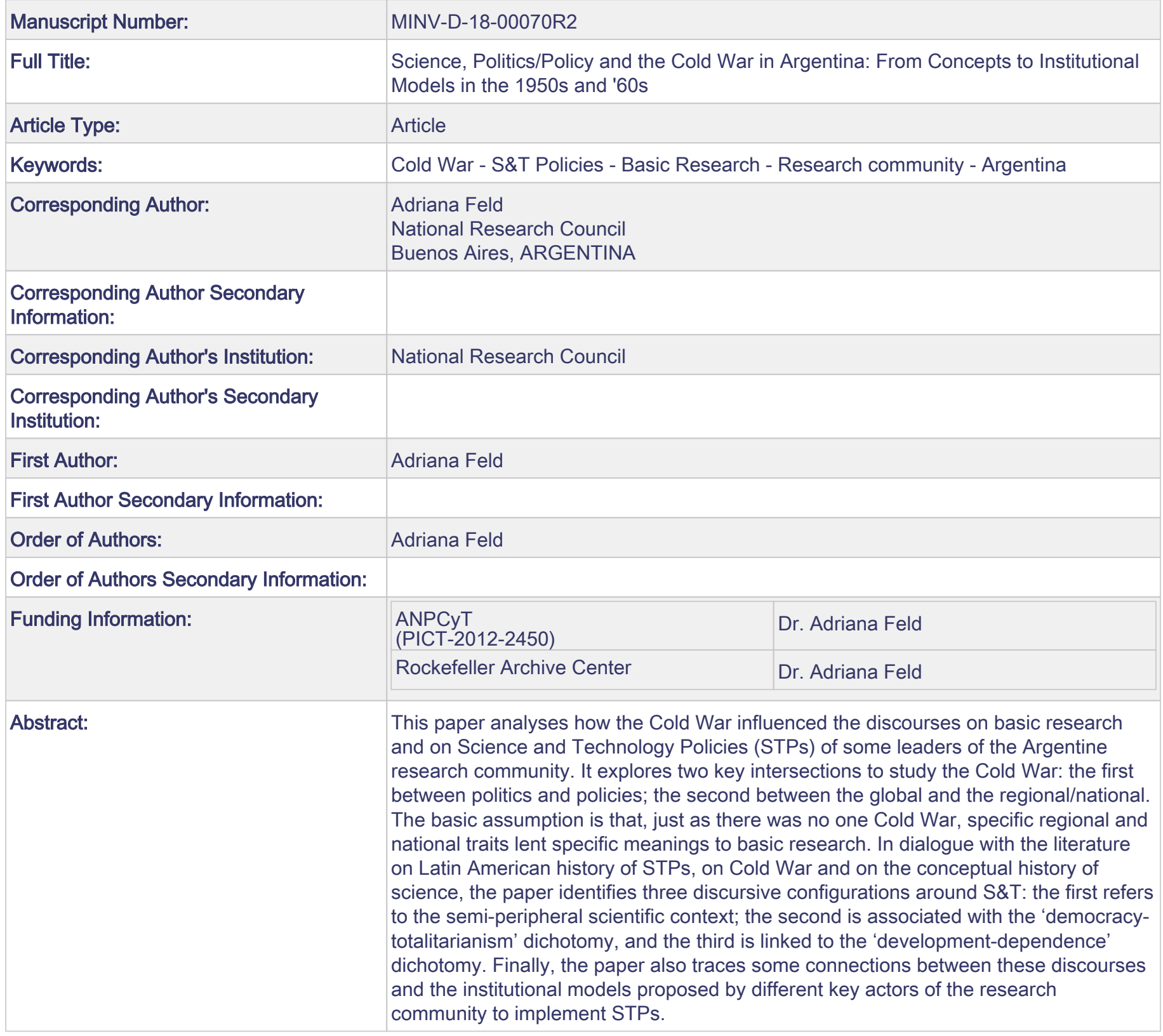




\title{
Science, Politics/Policy and the Cold War in Argentina: From Concepts to Institutional Models in the 1950s and '60s
}

\author{
Adriana Feld \\ National Scientific and Technical Research Council (CONICET) \\ STS Centre, Maimonides University \\ feldri75@yahoo.com.mx
}

Telephone No : 00541120511939 (ext. 104)

\begin{abstract}
This paper analyses how the Cold War influenced the discourses on basic research and on Science and Technology Policies (STPs) of some leaders of the Argentine research community. It explores two key intersections to study the Cold War: the first between politics and policies; the second between the global and the regional/national. The basic assumption is that, just as there was no one Cold War, specific regional and national traits lent specific meanings to basic research. In dialogue with the literature on Latin American history of STPs, on Cold War and on the conceptual history of science, the paper identifies three discursive configurations around S\&T: the first refers to the semi-peripheral scientific context; the second is associated with the 'democracy-totalitarianism' dichotomy, and the third is linked to the 'development-dependence' dichotomy. Finally, the paper also traces some connections between these discourses and the institutional models proposed by different key actors of the research community to implement STPs.
\end{abstract}

Keywords: Cold War - S\&T Policies - Basic Research - Research CommunityArgentina 


\section{Science, Politics/Policy and the Cold War in Argentina: From Concepts to Institutional Models in the 1950s and '60s}

\section{Introduction}

The Latin American science and technology policies (STPs) of the 1960s have been prone to various interpretative tensions. On the one hand, as Vessuri (1996) points out, the period witnessed a process of modernisation, professionalisation and institutionalisation of scientific research, particularly in the universities. In Argentina, many actors consider the period between 1955 and 1966 the 'golden age' of national science. This process also coincided with the so-called 'golden age' of international assistance for Latin American universities and research centres, pioneered by such North American public bodies and foundations as the Ford or Rockefeller Foundations, but also provided by international organisations like UNESCO (Levy 2005).

However, there are several critical interpretations of this period regarding both the internationalisation of research and STPs. If, as Kreimer (2006) has claimed, the lack of orientation of research agendas led to a modality of 'liberal internationalisation' whereby the leaders of local Argentinian laboratories negotiated their agendas with their European or US peers, many authors have highlighted the predominance of a 'linear' or 'supply-based' model in STPs (Dagnino and Thomas 1999; Kreimer 2006; Sagasti 2011; Velho 2005). Although these references to the so-called 'linear model' follow a more general trend in science studies initiated in the 1980s and '90s, some Latin American uses of the term in the academic literature differ from the 'standard' definition. ${ }^{1}$

While some mentionings of the 'linear model' seem to refer to concentration 'on the scientific end' of the innovation chain (known as the science push model), others allude to something similar to the concept of 'supply side' used by Freeman (1982) to describe the first phase of post-war STPs in the more advanced countries: namely, the strengthening of R\&D capabilities. Sometimes both terms ('supply based' and 'linear model') are associated within the same text, giving rise to misunderstandings. Furthermore, many authors agree on the key role of the 'research community' in Latin American STPs, and there is broad consensus around the idea that STPs have been the result of the imitation or diffusion of (successful) foreign models (Albornoz and Gordon 2011; Dagnino and Thomas 1999; Finnemore 1993; Oteiza 1992). ${ }^{2}$

Inspired by these critical perspectives, I tackle the following questions: What were the meanings attributed to 'basic research' by the Argentinian research community? How did the Cold War mould those meanings? Did local actors uncritically copy a 'supply based' or 'linear model' discourse? To answer these questions, I will examine the perspectives of

\footnotetext{
1 According to Edgerton (2004), a standard definition could be: "[... "basic" or "fundamental," "pure" or "undirected" scientific research is the main source of technical innovation; the process of innovation is a sequential one, by which discoveries arising in such research are developed in a sequence through applied research, development and so on, to production. Overall, the innovation produced is the main source of economic growth.' (Edgerton 2004: 2)

2 They provide many explanations for this: the lack of industrial demand, the delegation of the task on the research community by the political leaders, the contradictions between 'explicit' and 'implicit' policies (Herrera 1973) or the insensitivity of the research community to the socioeconomic demands.
} 
certain leaders of the Argentinian research community in light of two research lines: studies on Cold War science and the cultural Cold War, on the one hand, ${ }^{3}$ and the conceptual history of science, technology and innovation, on the other. ${ }^{4}$

While much recent historiography on Cold War science has emphasised that the Cold War moulded science and discourses about science in various ways depending on national contexts (Oreskes 2014; Heyck and Kaiser 2010; Van Dongen, Hoeneveld and Streefland 2015; Solovey 2001) ${ }^{5}$, studies on the Cold War in Latin America have emphasised the need to observe the uses, meanings and local responses to the global conflict: that is, how Latin American actors have translated the global geo-political tensions into their own terms, or have used them to further their own agendas (Grandin 2002; Joseph 2008; Iber 2015; Calandra and Franco 2012). Along similar lines, I will show that, just as there was no one Cold War, specific regional and national traits (scientific, political and economic) lent unique meanings (political and epistemic) to basic research, which had an impact on how the institutional organisation of STP was conceived.

To this end, I analyse the stances and attitudes of three leaders of the most 'academic' sector of the Argentinian research community, who held key posts during the institutionalisation of STPs and university modernisation between 1955 and 1966. The first is the physiologist Bernardo A. Houssay (1887-1971), a founding member and leader of the Argentinian Association for the Advancement of Sciences (AAPC), created in 1933, a Nobel Prize winner (1947) and first President of the National Scientific and Technical Research Council (CONICET), created in 1958. The second is the philosopher Risieri Frondizi (1910-1985), Rector of the University of Buenos Aires (UBA) (1957-1962) and brother of the president Arturo Frondizi (1958-1962). The third is the meteorologist Rolando García (1919-2012), Dean of the UBA's Faculty of Exact and Natural Sciences (FCEN) from 1957 to 1966, first Vice-President of the CONICET from 1958 to 1963 and CONICET Board Member until 1965. To fully understand the so-called 'golden age' (1955-1966), I will summarise some key elements of the previous decade that marked these actors' outlooks by the mid-1950s.

As well as mapping the basic concepts presented in the literature, the first section tackles the meaning of the emphasis on basic research in a semi-peripheral context of the 1940s and ${ }^{\prime} 50$ s. $^{6}$ In the second and third sections, I explore two key intersections in the study of the

\footnotetext{
${ }^{3}$ Mateos and Suárez Díaz (2012) warn that, compared with case studies on developed countries and more recently with studies on countries like China, India and South Africa, the history of Cold War science in Latin America has been in short supply and disconnected from the debates in the international community of science historians.

${ }^{4}$ A triggering text in the STS field was probably a paper by Otto Mayr (1976), where he pointed out that the concepts of 'science' and 'technology', like the values accorded to them and the ideal relationship established between the two terms, are historically and geographically located. For example, for the Cold War period, Kleinman and Solovey (1995) have shown how the same social actor or institution, the National Science Foundation (NSF), at the same historical moment (the 1950s) resorts to contradictory rhetorical repertoires - the apolitical nature of basic science, on the one hand, and its potential to fight communism, on the other - in order to defend its interests against various situations or actors.

${ }^{5}$ For example, Solovey (2001: 168) points out that 'political struggles on both sides of the Iron Curtain helped to shape what did and did not count as legitimate science'.

${ }^{6}$ Among Latin American countries there are significant differences in size, availability of natural resources, economic diversification, industrialisation level, social development and scientific tradition. Compared to other countries in the region, at the end of the Second World War, Argentina had a relatively diversified and industrialised economy, a high income per capita, high levels of alphabetisation and an important scientific tradition in some disciplines like physiology (Thorp 1998). For that reason, I prefer the term 'semi-peripheral' to 'peripheral'.
} 
Cold War: the first between politics and STPs; ${ }^{7}$ the second between the global and regional/local levels. More specifically, I go into how global geo-politics - Cold War politics - and local Argentinian politics were joined up in different discourses about the most appropriate type of research. The exposition in these two sections is chronological and examines the formation of discursive nuclei and contextual elements: the first nucleus (section 2), embodied in the figure of Houssay, took shape against the background of sociopolitical polarisation during the government of Juan Domingo Perón (1946-1955); the second nucleus (section 3), embodied in the figures of Frondizi and García, gained ground in a climate of ideas marked by the advance of a developmentalist ideology with anti-imperialist overtones since the military government of the so-called 'Revolución Libertadora' (19551958).

\section{Conceptual Aspects: The Linear Model, Science, Técnica and Doctors in a Semi- peripheral Context}

According to Edgerton (2004), since the 1980s and '90s, some authors attributed historical agency to the 'linear model' (as if it really existed in the minds of policymakers), while others felt that, having been dominant in the academic literature, it should be criticised as a myth. However, Edgerton shows that, before those decades, innovation studies did not mention this model, nor did economists see a positive correlation between R\&D expenditures and economic growth. What is more, the evidence (like US distribution of R\&D expenditures in the post-war period) demonstrates that there was no actual STP based on the linear model.

Similarly, although the origin of the 'linear model' has often been attributed to the wellknown Vannevar Bush Report (1945), authors like Edgerton (2004) and Godin (2009) stated that there is nothing resembling a linear model as a theoretical framework for STP in that report, but rather a lobbying, a claim of the significance of 'basic' as opposed to 'applied' research, particularly favoured in terms of funding.

Following this line of thought, Schauz (2014) emphasises that the concept of 'basic research', contained in the Bush Report as a boundary marker for policymakers in resource allocation, was a polysemic concept that took on different meanings depending on the actor and the public. ${ }^{8}$ The US scientific community, especially in universities, attributed a meaning to it more akin to the 19th-century notion of 'pure science' - the search for truth and the principles governing nature - as a way of indicating an epistemic and moral superiority that would help them face the ethical dilemmas (military demands on the research system) and ideological pressures (funding subject to ideological control) of the Cold War. On the other hand, from a political standpoint, the image of independent, neutral, impartial 'pure science', as proposed by Merton (1942) and Polanyi (1962), was a good representation of the US model of liberal democracy, contrasting with the Nazi and Soviet regimes. ${ }^{9}$ But the concept of basic research

\footnotetext{
${ }^{7}$ In her work on science studies during the Cold War, Aronova (2012: 307) points out that the years prior to the formalisation of STP studies were when 'the issues of science politics appeared inseparable from those of science policy, science organisation, and science governance'.

${ }^{8}$ On this concept, see also Pielke (2012).

${ }^{9}$ Regarding this topic, Godin points out that the dichotomy between 'pure' and 'applied science', that can be traced back to the 19th century, 'was a rhetorical resource used by scientists, engineers and industrialists for defining, demarking and controlling their profession (excluding amateurs), for financial support (to scientists), for rising the status of a discipline (as engineers did), and for attracting scientists (as industrialists did). It was also a rhetoric, particularly present in Great Britain that referred to the ideal of the freedom of science from
} 
was also used to address a wider audience as a way of emphasising the social and economic utility of research in response to growing social expectations from science. The concept thus bore a certain familiar resemblance to that of 'fundamental research', which gained ground after the First World War in applied fields (engineering sciences and industrial research, or plant breeding) (Kaldewey and Schauz 2017).

Nevertheless, the term 'basic research', disseminated by the Bush Report (1945), clearly came to prominence in global science policy as a result of the United States' post-war hegemony (Kaldewey and Schauz 2017). Latin American scientific elites were no exception: as internationalised actors, they too resorted to internationally legitimised rhetorical repertoires to employ them for their own purposes. In 1946, the journal Ciencia $e$ Investigación (CeI), an organ of the AAPC, summarised and discussed the Bush Report in an article entitled 'El futuro científico de los Estados Unidos' [The Scientific Future of the United States], and cited it frequently when discussing local issues (Hurtado de Mendoza and Busala 2002a: 38).

Expressions of the 'linear discourse' often attributed to Bush can also be found in the discourses of this history's various protagonists, although there seem to be no clear patterns in terminology use, with local actors resorting to different terms like 'basic research/science', 'pure science', 'fundamental research/science', and even 'science' or 'scientific research'. For example, in 1954, Houssay stated:

The division between pure (or theoretical and fundamental) science and applied science is, in principle, artificial, for it is more accurate to say there is science and applications of science $[\ldots]$

Researches in the fundamental sciences must be conducted without regard for whether or not they will find an immediate application. Every genuine discovery will sooner or later be applied. Fundamental research provides the greatest and most fruitful discoveries, while applied researches solve more limited problems (Houssay 1954: 330).

Years later, Rolando García (1963: 9-10) pointed out: 'Scientific research cannot be considered [...] as a consequence of industrial development, but as a condition that must precede both technological research and industrial development'.

If we place those discourses in contexts with low levels of institutionalisation and professionalisation of research, it is possible to assign them a specific meaning different from the one it had in more advanced countries. Certainly, until the late 1950s, Argentina effectively lacked the state - and private - machinery to promote the development of research capability: scholarships, grants or full-time posts were scarce and unstable instruments, implemented with uneven criteria, and heavily dependent on institutional or disciplinary dynamics and the bargaining power of the actors. Consequently, while there was a significant tradition in biomedical research and various disciplines of the taxonomic sciences cultivated in observatories and museums set up in the 19th century, universities had a clear professionoriented profile, and, biomedicine apart, the experimental sciences were rather weak. As Cueto (1994a: 235) points out, this was why Houssay, a spokesman for Argentinian science well before his Nobel Prize, 'engaged in a crusade to redefine academic life in Argentina and wrote articles advocating research as the university's primary function, a limit on the number

interference from the State, with an eye to the counter-reference and negative experiences in Nazi Germany and to some extent in the Soviet Union' (Godin 2009: 29-30). 
of students admitted into medicine, and the importance of laboratory work and full-time positions in the basic sciences'. ${ }^{10}$

At the same time, in the 1940s and '50s, several members of the scientific elite explicitly differentiated scientific research from other professional practices to lay publics. In 1942, Houssay made the following distinction:

If we call the man dedicated to original scientific research a man of science (savant in French), doctors, engineers and lawyers should not be considered men of science. It is a common error of journalists, men of the theatre and novelists to describe medical practitioners as men of science and to attribute to them the invention of sera or curative treatments (cancer or infantile paralysis), when in reality these inventions are made almost exclusively by specialist men of science fully engaged in scientific research (Houssay 1942: 310).

In the early 1940s, certain members of the scientific elite also resorted to this kind of 'boundary work', as Gieryn (1983) might term it, with engineers, industrialists and politicians in order to differentiate 'science' (as synonymous with 'research') from 'técnica' and analytical public labs from research labs (Feld 2015). Associated, in the social imaginary of the 1940s and '50s, with a wide range of activities, from research to highly professionallyqualified routine work, the Spanish word 'técnica' joined together the English concepts of 'technique' (rules, procedures and skills for achieving specific goals) and technics (material aspects of industry), without a clear differentiation from 'technology' (as applied science). ${ }^{11}$

Similarly, in the mid-1950s, Risieri Frondizi saw the need to introduce a criterion (classic in the developed countries by that time) in order to differentiate professional from research training:

It may be advisable to separate the degree of 'Doctor' from any professional title and to grant it only to those who have carried out intensive studies and passed an original thesis, demonstrating an effective vocation and other requirements for creative work. In the future, possessing the title of 'Doctor' should - save in exceptional cases, where justified - be the sine qua non for starting a career as a lecturer or researcher (Frondizi 1956: 321).

If there was a common concern to distinguish research from other activities, the transformation of research practices occurring in developed countries during the 1940s and '50s caused tensions when it came to defining how and what research should be done in the local context. Some of the CONICET Board's discussions show that Houssay's position was based on a traditional model stemming from his own 'old style' of work during the first half of the century, that implied the use of simple and relatively accessible equipment and materials (Cueto 1994a). On the contrary, the model consolidated since the Second World War was more complex, based on more sophisticated techniques and equipment, and

\footnotetext{
${ }^{10}$ Between 1915 and 1919, Houssay worked full-time in the non-university Institute of Bacteriology, run by the Austrian Rudolf Kraus. In 1919, he was appointed to the chair of physiology at the Medical Faculty (UBA), where he set up the Institute of Physiology and sent students of his to the United States with financial support from the Rockefeller Foundation. In the 1930s, he embarked on a strategy of provincial diversification by installing two students of his in the universities of Rosario and Córdoba (Cueto 1994a; Buch 2006).

${ }^{11}$ On the history of the concepts 'technique' and 'technology', see Schatzberg (2006) and Salomon (1984). On the construction of technology as applied science, see Kline (1995).
} 
consequently dependent on larger - sometimes colossal - amounts of money. ${ }^{12}$ Illustrating the tensions between the two models, Rolando García related that, when he suggested purchasing a computer for the FCEN's Calculus Institute to the CONICET's Board, Houssay objected on the grounds that 'he had won the Nobel Prize without the need for such expensive tools' (García 2003: 59). Years later, Luis F. Leloir - an ex-student of Houssay, a member of the first CONICET Board and a Nobel Prize-winner in 1970 - would proudly recall having manufactured a refrigerated centrifuge out of an old washing machine, tyres and ice cubes (Leloir 1989). Houssay's or Leloir's difficulty understanding the theoretical and experimental challenge of such emerging fields as molecular biology also became apparent in 1962, when César Milstein (Nobel Laureate in 1984) asked Leloir for a position at his institute and Leloir replied that molecular biology was merely an auxiliary technique of biochemistry and that, sadly, he could not help him (Kreimer 2010: 134).

The different models endorsed by Houssay and García aside, a good indicator of the changes in research practices is the extent of foreign funding required by research institutes for purchasing equipment: whereas, in 1944, Houssay's institute received a four-year grant of US\$29,800 from the Rockefeller Foundation (Cueto 1994a), in 1961, the Ford Foundation awarded the FCEN's Physics Department (supported by Dean García) a five-year grant of US\$429,000 (Ford Foundation 1966). While this difference partially arises from the specific features of each field and from changes in US assistance policy to Latin American universities, it is also attributable to García's desire to align local research practices to the new paradigm.

Below, we will see that the tensions between the two conceptions of how and what research was or should be done overlapped with political divergences.

\section{Science and Democracy: Houssay and the Local Interpretation of the Global Cold War}

One of the tensions that arose after the Second World War was between an 'academic' and a 'bureaucratic' culture (Elzinga and Jamison 1996). The actors carrying the former gradually consolidated their position in response to the triple threat posed by scientific secrecy, authoritarian political regimes trying to mould science to their doctrines and the increasing demand for knowledge applicable in the short term (Schauz 2014). Against this background, autonomy and self-regulation became scientific values of the academic culture, while basic research was linked to values of freedom (of scientific research and communication) and democracy. Bureaucratic culture was, in turn, concerned with managing the increasing public investment in R\&D and with justifying the state's efforts regarding civil society.

In the early 1950s, many members of the intellectual and scientific elites heading up (or belonging to) international organisations, like Julian Huxley, the first director of UNESCO (1946-1948), or Michael Polanyi, chair of the 'Science and Freedom' Conference (Hamburg, 1953), expressed great concern about how to guarantee freedom in science. The 'Science and Freedom' Conference was organised by the CIA-financed Congress for Cultural Freedom (CCF), an anti-communist cultural initiative set up in Berlin in 1950 in response to Soviet

\footnotetext{
${ }^{12}$ Several studies have shown different aspects of the changes in research practices after the Second World War. Rabkin (1987), Morris and Travis (1997), Brenni (1997) and others, for instance, refer to the use (and production) of new instruments. Other authors termed this process the emergence of 'big science' (Price 1963; Galison and Hevly 1992).
} 
cultural diplomacy deployed through local communist parties and the World Peace Council. ${ }^{13}$ According to Edward Shils, who joined the CCF in 1953, the Hamburg Conference had been called 'to summon the attention of the world to the damage done to science by totalitarianism' and to consider 'the urgent problem of how to prevent encroachments of the autonomy of intellectual life and institutions, at a time when the state demands so much of science and when politicians are so doctrinaire or so boundless in their aspirations' (Shils 1954: 151). ${ }^{14}$ Polanyi's answer was the perfect example of the academic culture: he justified the freedom of pure science assimilated to the functioning of the free market but believed that applied science could be incorporated in the network of practical actions (Shils 1954: 152).

This key tension, which emerged in more advanced countries, broadly framed the relationship between the Perón administration (1946-1955) and Argentina's scientific elite. Perón's rise to power, preceded by a military government (1943-1946) in which he himself officiated, marked the start of a conflictive relationship with the scientific and intellectual elite. In 1943, after the governmental take-over of the universities and neutrality over the War (maintained until 1944), several prestigious scholars (Houssay among them), intellectuals and members of political parties identifying with democratic values and anti-fascist and pro-Allies movements signed an opposition manifesto and were dismissed from their university posts (Nállim 2006). Despite the universities' return to normality in 1945, Perón's triumph in the 1946 presidential election was followed by a new governmental take-over of the universities and a fresh wave of lay-offs and resignations (Buchbinder 2005). ${ }^{15}$ In that context, during the first half of the 1940s, while raising the flag of democracy, many intellectuals and political figures translated their anti-fascism into anti-Peronism. What is more, some of them considered Perón as a local version of totalitarianism (Plotkin 2007; Nállim 2014). This opposition was part of a broader political and social division that arose in those years: supporting Perón, the working class, some conservative leaders, the Church and the Army; on the other side, business organisations, the middle and upper classes, and a broad political spectrum (socialists, communists and the Radical Party) (Romero 1994).

Regarding STPs, two opposing discursive configurations developed during Perón's administration, expressing a struggle for the legitimacy of two conceptions of how to organise knowledge production (Hurtado de Mendoza and Feld 2010). Other events added fuel to the fire, like the taking-over of various academies, and the (secret) atomic energy research project, started in the late 1940s after the recruitment of the Austrian physicist Ronald Richter (known as 'The Richter Affair'). ${ }^{16}$ For sure, the secrecy and military control over the atomic project, the exclusion of the local scientific elite and Richter's failure to fulfil

\footnotetext{
${ }^{13}$ One of the studies that marked the today extensive literature on the CCF is Stonor Saunders (1999). For a recent historiographical review, see Scott-Smith and Lerg (2017). The CCF in Latin America is dealt with in Iber (2015) and Glondys (2018).

${ }^{14}$ Edward Shils later became founding editor of Minerva. On the CCF's involvement in science and science policy journals, see Aronova (2012) and Wolfe (2017).

${ }^{15}$ In 1944, after his dismissal, Houssay created a private institute, the Institute of Biology and Experimental Medicine, supported by the Argentinian Sauberán Foundation and the Rockefeller Foundation. Other private biomedical research institutes (the Centre for Cardiological Research and the Campomar Foundation) were set up in those years in response to the difficult situation in universities. At the same time, many opposing intellectuals, professionals and scientists actively participated in cultural forums like the Colegio Libre de Estudios Superiores that were outside official institutions (Neiburg 1988).

${ }^{16}$ After Germany's defeat in the Second World War, members of the Argentinian Armed Forces worked abroad to recruit German engineers, scientists and technicians. As part of that operation, Kurt Tank, chief designer and director of the Focke-Wulf factory between 1933 and 1945, arrived in Argentina in 1947 and became the leader of Perón's flagship technological project: the fighter jet known as Pulqui II. It was Tank who recommended hiring Richter (Artopoulos 2012).
} 
the promise of unlimited low-cost energy were probably some of the elements that triggered the discourse of freedom in science and culture. ${ }^{17}$

This project and other technological and industrial projects in strategic sectors (like aeronautics or the iron and steel industry) were inspired by the industrialist vocation (for civil and defence purposes) that emerged in a sector of the military in the 1930s. Indeed, Perón aimed at strengthening and diversifying the process of import substitution industrialisation, relying on a set of promotion instruments (credits, preferential exchange rates for imported machinery and raw materials, increased duties and so on), a policy of income distribution, economic planning and direct state intervention through public (civil and military) enterprises (Belini 2009: 11, 21). Within this frame, scientific activity in the official discourse was subsidiary to technical and industrial development, with an emphasis on militarily and economically strategic sectors and the 'welfare of the people' (Hurtado de Mendoza and Busala 2006). These elements are clearly reflected in Mundo Atómico, which, presented as a 'scientific dissemination magazine', was also a channel to spread the official rhetoric and a political propaganda instrument of the 'new scientific Argentina' (Hurtado de Mendoza and Feld 2010). The magazine highlighted emblematic technological projects under military control (like the development of atomic energy and the Pulqui II jet fighter), but also stressed the civil uses of atomic energy and of the state-driven industrial undertaking in producing durable consumer goods in the automotive sector. ${ }^{18}$ Moreover, it included articles about infrastructure works (dams, airports, monuments) and the improvement of public health services. In general terms, the journal joined up the concepts of 'science' and 'técnica' in keeping with the popular imaginary, where the boundaries between techniques, technics and technology (or between research and professional practice) were hazy.

Discourses and technological development projects were combined with the creation of STP bodies responsible for drawing up plans to guide research. In 1950 and 1951, the government created the National Technical Research Department (DNIT, later the DNICyT) and the National Scientific and Technical Research Council (CNICyT). The latter, composed not of scientists but representatives of various government bodies and national universities, was responsible for drafting the Second Research Plan, and acted as a link between government and the 'research contingent' (Hurtado de Mendoza and Busala 2006; DNICyT n.d.: 91). The Charter on the 'Conduct of Scientific and Technical Research' also provided for the creation of a National Research Fund aimed principally at funding research in ministerial bodies, and complementary research in universities, academies and scientific societies previously agreed by contract (DNICyT n.d.: 96).

Although neither the CNICyT nor the National Research Fund were ever fully operational, some documents highlight a conception of STPs in which the academic culture should be subordinated to the bureaucratic culture. One argued that 'The great evolution of the sciences

\footnotetext{
17 Richter arrived in Argentina in 1948 and seduced Perón with the idea of developing an innovative, experimental method (thermonuclear fusion reactions) to obtain unlimited low-cost energy. With strong government support, the physicist installed himself on Huemul Island, in Bariloche, where laboratories were built and experiments conducted under the strictest secrecy. In 1952, the government set up a technical oversight commission, whose reports were unfavourable and led to the project's closure (Mariscotti 1985: 225).

18 In 1952, the same year as the closure of the Huemul Project, the government redefined the goals of the Aerotechnic Institute, where Tank had developed the Pulqui II, transforming it into an aeronautical and automotive complex. Artopoulos (2012) explains that this reorientation was part of a broader change in economic policy, based on the diminished prospects of a new world war and on the decision to focus on the development of capital goods (machinery and vehicles) and industrial inputs (steel, aluminium and chemical products).
} 
and other professions over the last twenty years in the United States of America has brought the realisation that during the emergency period of 1940 the policy of laissez-faire regarding the problem of the distribution of scientific staff will have to be changed' (Registro Científico Nacional 1955: 10). An article in Mundo Atómico stated: 'The element of [scientific and technical] coordination must be external to the researchers themselves' (Mundo Atómico 1950: 17).

On the other hand, in 1945, the Argentinian scientific elite grouped around the Argentinian Association for the Advancement of Science (AAPC) began to publish the journal Ciencia e Investigación $(\mathrm{CeI})$, in which it presented its own view of science and science policy. ${ }^{19}$ Many editorials and articles reflected the discussions developed in the international scenario among the members of the scientific elite. For example, in 1950, CeI partially reproduced an article by Julian Huxley that referred to the situation of the soviet genetics and followed the same line of concerns expressed in the 1953 Conference on Science and Freedom:

How should men of science act in the face of the increasing concern of the state with science and the consequent increasing pressure of the state on science?

Can they accept the existence of an official scientific policy? Can they accept the possibility that the majority of men of science shall be paid by the state and that the major cost of scientific work shall be borne on Government funds? Can they accept official direction as to what subjects shall be investigated? (Huxley 1950:131). ${ }^{20}$

The answer to these questions did not aim to delegitimise science policy but to limit its scope. Huxley differentiated fundamental from applied research, asserting that 'major advances in scientific knowledge cannot be planned to order' and that 'new possibilities of practical advance often derive from the most unexpected quarters, including investigations undertaken with no practical aim.' Therefore, the state 'should leave a considerable "unplanned sector" of fundamental research to the free choice of pure scientists.' (Huxley 1950: 131-132).

These themes were discussed in $\mathrm{CeI}$ with reference to national and international events. In 1946, the year Perón was elected president, Bernardo Houssay, then president of the AAPC, published an article entitled 'Science needs an environment of freedom', warning that 'in all countries that adopt totalitarian methods, there is a decline in scientific activity' because they 'exalt a faith or a mysticism [...] that undermines the truth and free examination' (Houssay 1946: 326). A similar warning was presented in an editorial on the Executive Power's decision to take over the academies, 'subjecting them' to the 'direction and control of the state'. The editorial added that, 'in National Socialist Germany, Fascist Italy and, above all, Soviet Russia, academies have been converted into organs not of society but of the state', forced to adopt the official ideology, out of which 'we have seen the already deceased embryo of an 'Aryan physics' and 'Mendelian genetics' (CeI 1953a: 1-2).

In 1954, Houssay gave a lecture at a Columbia University symposium, 'Responsible Freedom in America', in which he stressed the association between science and democracy in two dimensions: an axiological one (with scientific practice disseminating democratic customs and values) and a political one (with science only being able to develop in a democratic environment):

\footnotetext{
${ }^{19}$ For an in-depth analysis of this journal, see Hurtado de Mendoza and Busala (2002a).

${ }^{20}$ The article appeared in 1949 in Nature and in the Bulletin of the Atomic Scientist.
} 
There are two major tendencies in the appreciation of the social role of science and between them lie several intermediate positions. For some, the role of science is to acquire new knowledge and find truth, elevating the human spirit. For others, science is an effort to meet the material needs and desires of everyday life. In its extreme form, this last position leads to the conclusion that men of science cannot be given the freedom to choose the object of their investigations; these must be directed and planned. Thus S.I. Vavilov has claimed that 'the days of so-called pure science are gone for good in the land of the Soviets', an expression that has been imitated by certain South American leaders [...] Diametrically opposed is the democratic countries' concept. There, science is the search for knowledge and truth, respecting originality and individual personality, with freedom of research, expression and criticism. Science is considered an independent value of great importance both intellectually and morally (Houssay 1954: 330-331).

It is not by chance that, one year after this lecture, Houssay was appointed Honorary President of the Argentinian Association for Cultural Freedom (AALC), the local branch of the CCF, for whom Peronism 'represented an example of right-wing totalitarianism, a traditional Latin American-style dictatorship which, in the context of the Cold War, could be functional to Soviet Communism' (Nállim 2014: 3).

The political aspects of science were closely bound up with policy. In a context where local dichotomies like Peronism-anti-Peronism reflected global dichotomies like democracytotalitarianism, $\mathrm{CeI}$ also expressed a concern about government tendencies to centralisation or planning and introduced a difference between the scope of técnica (a word in the official rhetoric) and science. In 1951, when the CNICyT was created, the journal's editors welcomed the initiative, noting that a prerequisite for its smooth functioning was respect for freedom of information, action, discussion and publication, and stating that 'any attempt by the National Council to direct research is doomed to failure' because 'one cannot commission a discovery and point the way to making it'. In contrast to Mundo Atómico, this journal stated that 'if the Council is to be effective in its management, it will have to be constituted by a majority of active researchers' (CeI 1951: 338-339).

Another article would stress the difference between técnica, considered as the state's responsibility, and science, which should be left to self-government by the academic community (mainly universities).

The confusion arises from the fact that no distinction is drawn between science and técnica, a shortcoming visible throughout the plan involving research [...] Technological research should be promoted by the state where it serves to meet current needs [...] The promotion of scientific research should be governed by other rules [...] Scientific research is not a function of the state. The state's role is auxiliary and supplementary ( $\mathrm{CeI}$ 1953b: 529-531).

This conception of science, técnica and STPs would find its correlate in the way the institutional organisation of STP was conceived following the overthrow of Perón. During the military inter-regnum of the so-called 'Revolución Libertadora' (1955-1958), public institutions were 'de-Peronised', the university system regained its autonomy and different public research organisations, like the CONICET, the National Industrial Technology Institute (INTI), the National Agricultural Technology Institute (INTA) and the National Atomic Energy Commission (CNEA) were created or reorganised. In the heat of the discussion about the fate of the STP bodies created under Peronism, the Minister for 
Education tasked a working group from the National Academy of Exact, Physical and Natural Sciences (ANCEFN), which included Houssay and his disciple Eduardo Braun Menéndez (co-founder of $\mathrm{CeI}$ and member of the CONICET's first Board), with outlining a project to set up a new National Research Council. Braun Menéndez expressed concern that the Council project proposed by the 'bureaucrats' had 'as one of its missions to help applied research (medicine, agronomy, public health, sociology, atomic energy and so on)' (Braun Menéndez to Beck, 16/1/1956). The ANCEFN President was then quick to suggest that the proposed Council be limited 'to sciences involved in the Academy itself, since the work to be completed in other fields like medicine, history, philosophy, literature, arts in general, agronomy and so forth has appropriate bodies to promote the advancement of these various branches' (ANCEFN 1958: 134).

For some of them, the projected Council was part of a long search for autonomy that almost ten years earlier had given rise to an unsuccessful project to create a private research university. ${ }^{21}$ However, this autonomy did not exclusively refer to the scientific community's self-government in developing 'pure science'. It entailed an institutional autonomy, not only from frequent governmental take-overs since 1930 but from student participation since the reformist movement of $1918 .^{22}$

\section{Science and Development: Anti-Imperialism and Developmentalism in Latin America}

By the mid-1950s, chronic crisis in some Latin American countries' balance of payments revealed that import substitution industrialisation was facing serious problems. At the same time, the availability of foreign public and private resources (for loans or direct investment) after the reconstruction of Europe seemed to offer a key to solve them. Against this background, developmentalism emerged as a compromise solution between the internal demands of industrialisation with state intervention and the international demands for economic opening (Sikkink 2009). As an economic model developmentalism entailed: 1) a policy of import substitution industrialisation focused on basic priority industries such as iron and steel, energy, chemical products, machinery, automotive and capital goods; 2) the use of public funds and foreign capital to support industrialisation; 3) growing state participation in orienting the development program through any form of indicative planning (Sikkink 2009: 4). Although there was some continuity with previous economic policies, the difference lay in the role attributed to foreign direct investment and international (technical/financial) assistance as transmitters of the capital, technology and practical knowledge required to strengthen, diversify and modernise the industrial sector.

The United States welcomed developmentalist governments, not only because of the new opportunities opened up for US companies but because they could act as a barrier to the expansion of revolutionary movements; they were considered a peaceful reformist path towards development. In fact, the issue of development and security was the pillar of the Point Four Program announced by President Harry Truman in 1949 as a technical assistance program for developing countries. In 1961, President John F. Kennedy launched the Alliance for Progress, with a similar purpose but different strategy, in response to hostile Latin American expressions to the US and the progressive displacement from the 'development or dependence' dichotomy to the 'development or revolution' one after the Cuban Revolution.

\footnotetext{
${ }^{21}$ On this project, see Hurtado de Mendoza and Busala (2002b).

${ }^{22}$ The literature on the University Reform is quite abundant. There is a good summary and bibliographical revision in Buchbinder (2005).
} 
In response to the two programs' strategies, some local actors attributed a new role and meaning to basic research.

In Argentina, the developmentalist project was led by President Arturo Frondizi, a figurehead of the Intransigent Radical Civic Union (UCRI), a branch of the Radical Party that originally had the support of a broad arc, both political (Peronism, then banned, and Communism) and social (the working class, sections of the national bourgeoisie, the middle class, students and intellectuals) (Altamirano 1998, Sikkink 2009). Frondizi's campaign emphasising economic independence (presented as a rupture with agro-export structures), which many voters associated with national ownership of industry and an anti-imperialist stance, would prove problematic at the start of his presidency, when the role attributed to foreign capital became explicit.

Progressive, left-leaning intellectuals who had remained in obscurity under Peronism found in Arturo Frondizi a presidential candidate with whom it was possible to share not only ideas but a common language and interests (Sigal 2002). Their number included a core of innovative lecturers and authorities linked to the university reform movement, who started a process of university modernisation as soon as the military government gave autonomy back to those institutions. This movement did not line up with the political parties but included representatives of the Socialists, Communists and members of the Radical Party (Sarlo 2001). They promoted a new model of the university in both political and academic terms. At least three basic principles came together in the political aspects: one linked to the government of universities, promoting the participation of lecturers, students and graduates in the management of faculties; the other two linked to the university's 'social function', which meant commitment to social and cultural development, on the one hand, and facilitation of access for the economically and culturally disadvantaged population, on the other (Sarlo 2001).

Concerning the academic component, the reformist authorities aimed to forge close links between teaching and research, following some of the features of the US research model. This implied renewing the teaching staff based on new selection criteria, increasing full-time positions and organising the university into departments in charge of planning research in each area, training students, advising the Faculty Council on the organisation of the departments' degrees and planning the unit's budget and procurement. This type of organisation, which saw research as a collective and programmatic activity, began to be implemented very early on in the FCEN, under the rectorship of Risieri Frondizi and the deanship of Rolando García (both with post-graduate studies in US). Unlike Houssay and his closest circle, who also aspired to a US-style university model but disagreed with student participation, the reformers tried to adapt the model to Argentinian public universities, which were characterised by a powerful student movement and a process of overcrowding as a result of upward social mobility. ${ }^{23}$

Risieri Frondizi, the presidential candidate's brother, was a key figure in this core of innovative professors and authorities. His speeches highlight a university ideal that strove to avoid both the 'isolation' of the 'ivory tower', and the 'full-blown militancy' of the 'servile university with no spirit of its own', like the one 'Perón attempted to impose' (R. Frondizi

\footnotetext{
${ }^{23}$ The idea that developed countries' university models could not be transferred uncritically to the local context in Argentina can be seen in Frondizi (1957) and García (1966).
} 
1956: 318). Frondizi's ideal was an autonomous, socially responsible university committed to national development:

The university has lived up to now with its back to the country. It has to be turned into an instrument of national transformation and progress. To do this, the University must maintain a permanent link with the major government departments and industries, and with the concrete problems of economy, society, health and education (R. Frondizi 1957).

From the same perspective, the reformists called on a conception of science that combined the universal with the national, deploying an altogether different discourse from the 'disinterested pursuit of knowledge and truth':

It is not enough, of course, for a university to do research: that is the universal aspect of the question. An important part of the task depends on the problems chosen as the subject of research [...] It is true that researchers are driven by the pursuit of truth, but the intellectual engine is just one side of it [...] From the technical level to the level of its highest philosophical speculations, the pursuit of knowledge is conditioned by action [...] Through knowledge, we become independent from nature, from our own limitations and, in our case, from foreign domination too (R. Frondizi 1957: 14).

In fact, this link between the local and the universal was pervaded by a clear anti-imperialist stance: 'A university that does not do research,' said R. Frondizi, '[...] has to live at the expense of the world's other institutions [...] There has long been talk - and with good reason - of the dangers of economic and political imperialism. Few, however, pay any heed to cultural imperialism' (Frondizi 1956: 316).

During his presidential campaign, Arturo Frondizi wove reformist alliances to develop general guidelines for his future research and higher education policy. In January 1958, before being elected, he met with a group of scientists to discuss the Scientific Reactivation Plan. The plan announced the creation of a fully autonomous, self-sufficient National Scientific Research Council, 'made up of specialists, experts and representatives from the universities, the major state bodies and private research institutions [...], with the purpose of planning, coordinating and promoting the country's scientific and technical development' based on priorities linked to the national program (the improvement and diversification of production, health and national defence) (Frondizi 1958: 10). The proposed institutional model approached the reformist ideals and was altogether different from the one proposed by Houssay and his colleagues. However, the military government decided to create a council before Frondizi became president.

With the arrival of Arturo Frondizi in government (1958-1962), a series of measures (among them, the authorisation to establish private universities and the contracts with foreign oil companies) caused a rift with the reformist movement. One of the controversial points was the US assistance programs to universities, which also led to differences between professors and students within the reformism. This led to a new discourse about the political meaning of basic science/research.

From the late 1950s, the scale of US research funding for Latin American universities and research centres rose significantly (Levy 2005). One of the first university assistance programs in Argentina was the National Commission for the Administration of the Economic 
Development Support Fund (CAFADE) Plan, which grew out of the above-mentioned Point Four Program. The underlying criterion of this program, managed by the International Cooperation Administration (ICA), was the economic 'modernisation' and technical progress of the production apparatus, which entailed 'applying' scientific and technical knowledge available in the developed countries. In 1964, Howard Leavitt, an official of the ICA's successor, the US Agency for International Development (USAID), stated:

The popularity of the Point Four program in 1949 was due in part to America's pride in its ability to share pre-eminent technical know-how, which, it was assumed could be simply and efficiently handed over to less developed countries of the world at minimum cost. Throughout the history of foreign assistance, it has become increasingly clear that technical knowledge alone is not sufficient to produce the fundamental changes in society necessary for development. The exporting of harvesting machines alone takes no account of the necessity for new training programs for mechanics (Leavitt 1964: 220).

Point Four's ideal of assistance was largely in line with the Frondizi administration's expectations of rapid industrial development. The CAFADE Plan was signed in February 1959 and drawn up by the Presidency of the Nation and Albion Patterson, Director of the Point Four Mission in Argentina. Some $18 \%$ of the Plan's budget was destined for universities across five fields: industrial engineering, agricultural technology, business administration, public administration and economics. However, due to strong opposition from a sector of the reformist student movement only $0.7 \%$ of the allocation for universities had been paid out by February 1961 (Califa 2011).

The communist intellectual Ernesto Giudici expressed a reason for such opposition: foreign assistance was related to the imposition of the US university model, namely, departmental organisation and, above all, an emphasis on basic studies, which expressed the 'Yankee interest in [...] training technicians to its taste and for its enterprises', while 'they produce specialised technicians in the mother country and then export them' (Giudici 1959: 34 and 63). ${ }^{24}$ According to Giudici, in the US university model scientism supporters were unconscious instruments of 'technocrats' and 'big monopolies', who had 'ousted and cornered [the pure sciences] in a small department of specialists' (Giudici 1959: 60 and 61). On the contrary, Giudici advocated a university model that would avoid both limited professionalism and abstract scientism; it was necessary to train professionals with a scientific base.

In 1959, amidst the debates about the CAFADE Plan, the Ford Foundation entered Argentina through a series of exploratory missions. Unlike the director of the Point Four Mission in Argentina (Patterson), who negotiated 'at relatively high official levels', the Foundation was ready to conquer the hearts and minds of the academic elites, even those who evinced an antiimperialist stance (Wolf et al. 1959). ${ }^{25}$ The Ford Foundation's strategy was probably the first

\footnotetext{
${ }^{24}$ As a member of the Communist Party, Giudici had also been one of the local spokespersons for the World Peace Council, the Soviet front organisation (equivalent to the CCF) set up in 1949 (Petra 2013). On the World Peace Council in Latin America, see Iber (2015).

25 The policy also involved a political turn in cultural diplomacy. Patterson explained to the Ford Foundation's experts that 'considering the nationalistic feeling within the University of Buenos Aires, it is important to enlist the University's participation in Point Four assistance' (Wolf et al. 1959: 2). In the same vein, Glondys (2018) shows that, between 1961 and 1964, there was an operation to dismiss local CCF representatives in Latin America, as a result of the new cultural diplomacy strategy of 'Opening to the Left' after the Cuban Revolution.
} 
step taken by the US towards the Alliance for Progress (1961) that aimed at longer-term capability and institution building (following US university models) and not just technical modernisation (Levy 2005). ${ }^{26}$ The Foundation aimed to 'export' development but also modern democracy, for which the ethos of science was crucial. ${ }^{27}$

The Ford Foundation mission carried out between July and August 1960 explored funding opportunities in 'basic science'. The talks the expert held with García and Risieri Frondizi largely explain the decision to go ahead with the funding of basic science (or fundamental research, both terms being referenced interchangeably):

We discussed in general terms the place of fundamental science in the country with limited economic resources. From one point of view, fundamental science is a luxury. Moreover, it is a commodity, which is easily exploitable. Viewed in this light, it is a misallocation of resources for a relatively poor country to devote substantial effort to basic science. The basic science can be imported from abroad, and a limited number of bright people who might be absorbed by fundamental science can be used more productively in applied fields directly relevant to industrial and general economic development. There is, however, another side of the story. Fundamental investigation, in whatever field, is part of the full intellectual apparatus of any country, which hopes to understand and be part of the twentieth century, in Western terms. Fundamental research is an integral part of good teaching at the graduate and post-graduate level [...] (to ensure) that the small segment of the work force represented by highly trained professional will be flexible and adaptable to meet changing requirements. In addition, the position that developing countries should confine themselves to applied fields is, in rector Frondizi's words, a kind of intellectual colonialism. The colonial countries are expected to apply the findings of science, just as they apply engineering concepts to the development of the country. They are not expected to develop independent intellects working in the frontiers of science, but rather to import this kind of learning (Notes on visit to Buenos Aires 1960: 34-35). ${ }^{28}$

This report shows that, while foreign funding for 'applied fields' was seen as a way to strengthen centres' economic domination over peripheries, basic research was presented (whether by genuine conviction or as a rhetorical strategy to capture the support of the more radicalised sectors of the reformist movement) as a sign of cultural independence. For local actors the opposite of basic research was not 'applied research/science' but 'the application of (foreign) science and technology'.

Moreover, in contrast to the student's opposition to foreign assistance that would become radicalised throughout the 1960s, the reformist authorities accepted resources from the US,

\footnotetext{
${ }^{26}$ Indeed, Ford Foundation experts referred to the Point Four Program in Argentinian universities as a 'shortterm program designed to produce results within a few years' (Wolf et al. 1959: 1). Cueto's (1994b) study on the role of the Rockefeller Foundation in Latin America during the first half of the 20th century showed that the purpose of 'exporting' the US university model was not new. But the beginning of the so-called 'golden age' of US assistance to universities altered the scope of the effort, involving not only foundations, but bi- and multilateral agencies (like the USAID and the IDB) (Levy 2005).

${ }^{27}$ A report by one Ford Foundation expert stated that 'In supporting science in Argentina, the Ford Foundation would be lending its weight to strengthening the rational, liberal forces in the country' (Notes on Visit to Buenos Aires 1960: 58). On the relation between Ford Foundation support to basic research and the diffusion of liberal values in Europe, see Krige (1999).

${ }^{28}$ This opposition between the 'local development of scientific research' and the 'application of foreign science and technology' also features in a speech by Rolando García (1963).
} 
even when defending independence from central countries. Years later García explained that, during his time at the FCEN and the CONICET, he established a clear distinction between 'pure' foreign grants (institutional grants awarded to a faculty, a department or the CONICET) and 'impure' foreign grants (those awarded to individual researchers) (García 1971: 15). The conviction behind this distinction was that 'pure grants' or loans (those he negotiated with the IDB and the Ford Foundation) allowed more autonomy when it came to defining goals and agendas.

\section{Conclusions}

As the critical perspectives on Latin American STPs point out, there has been a contradiction between 'explicit STP' (implemented by institutions like the CONICET) and 'implicit STP' (expressed, for example, in the attraction of foreign enterprises by developmentalist governments) (Herrera 1973). At the same time, it is also true that the research community played an important role not only in policymaking but in politics. Indeed, the Argentinian research community became a political actor as a result of the conflictive pattern of relationship with the State. This fact, as well as political instability and discontinuity, partially explains the virulence with which some of the tensions of the Cold War played out in Argentina's discussions around STP. This is why I have paid so much attention to the role of the research community, asking questions like: Did they uncritically adopt a supply-based or linear discourse? What was the local meaning of basic research? How did the Cold War mould that meaning?

Throughout this article I have shown that, if there was a 'linear discourse' (which is by no means clear), it was resignified at the local level and deployed according to local conditions, challenges and political traditions, and did not necessarily lead to slavish imitation. In the first section, I emphasised that this discourse was adapted to a semi-peripheral context with relatively weak scientific infrastructure, where efforts to establish concepts like 'science' (understood as 'research') or 'doctor' (as a synonym for $\mathrm{PhD}$ ) were based on the need to professionalise research. This was the consensus base on which the two divergent discursive configurations presented in the second and third sections coexisted during the 'golden-age'. However, changes in research practices after the Second World War (and generational differences between Houssay and García) led to discrepancies regarding the definition of research best suited to the local conditions.

The tensions between traditional and modern research practices overlapped with political divergences: two discursive configurations about research were infused with the global, regional and national dimensions of the Cold War. The global configuration referred to the 'democracy versus totalitarianism' dichotomy and was forged in the heat of socio-political polarisation under Peronism. Within this configuration, a meaning of 'basic research' was adopted that was close to the concept of 'pure science' and the opposite of 'técnica'.

The regional configuration referred to cultural independence and the 'development versus dependence' dichotomy in a climate of ideas marked by the advance of a developmentalist ideology with anti-imperialist overtones. Here the connotations of 'basic research' were close to the concept of 'fundamental research' (potentially applicable research geared to solving local problems); it was not the opposite of 'applied research' but of 'the application of (foreign) science and technology'. 
This highlights something already underlined by the sociology and anthropology of science: that the so-called 'research community' is not a homogeneous actor, and its definitions about what type of research is legitimate and how to organise or direct this research are built up - as Knorr-Cetina (1982) points out - from circulation in 'trans-epistemic arenas' across scientific and non-scientific, political and academic spaces. In this 'research community', just the way global geopolitical tensions acquired a specific meaning in the national and regional political contexts, the concepts of 'science', 'basic research', 'técnica' and so on were permeated by meanings that expressed local/regional problems: How to institutionalise and professionalise research activities with norms of its own as distinct from political norms? What is the role of basic research in a semi-peripheral country? How to steer a process of technical modernisation and productive development while maintaining certain levels of autonomy in the economic and cultural spheres?

These discursive configurations, taken up as rhetorical tools to face various actors (governments, the general public, the most radicalised sectors of the reformist movement, US agencies or foundations) or to respond to the challenges of a semi-peripheral context, also had an impact on how the institutional organisation of STP was conceived between 1955 and 1958, when the creation of the CONICET was under discussion. In 1960, when the Council was already operating, a report of the Ford Foundation summarised these differences in the following terms:

Houssay believes that the major function of the Council is to distribute fellowships and minor research grants [...] On the other hand, apparently García sees the Council as being [...] the central scientific body of Argentina, the group which can [...] serve the same function that the Academy of Sciences and the National Research Council serve in the United States (Notes on Visit to Buenos Aires 1960: 4).

In fact, in 1962, García maintained that 'a Research Council's existence in a country in no way implies that this country has a science and technology policy' (CONICET, 21/12/1962). In August 1963, he warned: 'Unless the government in some way takes research plans to be an integral part of its governmental action, influencing all the important decisions of the different ministries, the action of the Council and that of the universities may sooner or later lead to scientists only being trained for export' (García 1963: 12). For many reasons I cannot go into here, the CONICET would reflect Houssay's far more than García's ideas.

In the late 1960s, the failure of developmentalist policies to fulfil their promises and the shift towards authoritarianism in the region led to strong disenchantment in those who had initially supported developmentalist leaders. In Argentina, the process started with the modernisation of universities and the creation of the CONICET was abruptly interrupted in 1966 with a new military coup and the take-over of the universities. The new wave of resignations particularly affected one of the epicentres of the modernisation process: the FCEN. When reformist developmentalist optimism vanished, many actors who had enthusiastically participated in the 'golden age' expressed a critical view of that period. For example, Oscar Varsavsky, one of the innovative reformist professors, questioned the scientism of the 'scientific community': namely, the imitation of research agendas, values and evaluation criteria from developed countries (Varsavsky 1969). Varsavsky became a leader of what today we call Latin American Thought on Science, Technology and Development, a movement that influenced 
critical perspectives of the first professionalised practitioners of science studies in Latin America. $^{29}$

This paper is an attempt to step back and regard the history through the eyes of some key protagonists of the period 1955-1966. Interestingly, the range of options and interpretations was quite different at the beginning and at the end of the 1960s. At the start of the decade, while foreign funding for 'applied fields' or technical training was seen by reformers as a way to strengthen centres' economic domination over peripheries, basic research was presented as a sign of cultural independence. However, by 1970, reformers like García shared Varsavsky's criticism of scientism and foreign assistance.

\section{References}

Albornoz, Mario, and Ariel Gordon. 2011. La política de ciencia y tecnología en Argentina desde la recuperación de la democracia (1983-2009). In Trayectorias de las políticas científicas y universitarias de Argentina y España, eds. Mario Albornoz and Jesús Sebastián, 67-122. Madrid: Consejo Superior de Investigaciones Científicas (CSIC).

Altamirano, Carlos. 1998. Desarrollo y desarrollistas. Prismas - Revista de historia intelectual 2: 75-94.

ANCEFN. 1958. El Consejo Nacional de Investigaciones Científicas y Técnicas: una importante iniciativa de la Academia. Anales de la Academia Nacional de Ciencias Exactas, Físicas y Naturales 13: 131-135.

Aronova, Elena. 2012. The Congress for Cultural Freedom, Minerva and the Quest for Instituting 'Science Studies' in the Age of Cold War. Minerva 50(3): 307-337.

Artopoulos, Alejandro. 2012. Tecnología e innovación en países emergentes. La aventura del Pulqui II (1947-1960). San Isidro: Lenguaje Claro Editora.

Belini, Claudio. 2009. La industria peronista. Buenos Aires: Edhasa.

Braun Menéndez, Eduardo to Guido Beck. 16/1/1956. Carpeta Guido Beck. Bariloche: Archivo del Centro Atómico Bariloche.

Brenni, Paolo. 2013. Physics Instruments in the Twentieth Century. In Science in the Twentieth Century, eds. John Krige and Dominique Pestre, 741-757. London and New York: Routledge.

Buchbinder, Pablo. 2005. Historia de las universidades argentinas. Buenos Aires: Sudamericana.

Buch, Alfonso. 2006. Forma y función de un sujeto moderno. Bernardo Houssay y la fisiología argentina (1900-1943). Bernal: Editorial de la Universidad Nacional de Quilmes.

Bush, Vannevar. 1945. Science, the endless frontier. A Report to the President by Vannevar Bush, Director of the Office of Scientific Research and Development. Washington: United States Government Printing Office.

Calandra, Benedetta, and Marina Franco. 2012. Desafíos y límites para una nueva mirada de las relaciones interamericanas. In La guerra fría cultural en América Latina. Desafíos y límites para una nueva mirada de las relaciones interamericanas, eds. Benedetta Calandra and Marina Franco, 9-32. Buenos Aires: Biblos.

Califa, Juan Sebastián. 2011. El movimiento estudiantil reformista contra el CAFADE Plan. Cientificismo, imperialismo, reestructuración universitaria y lucha política. Redes 17

\footnotetext{
${ }^{29}$ On the subject of Latin American thought on science, technology and development, see Feld (2015, chapter 3). For a recent revision of the STS field in Latin America, see Kreimer and Vessuri (2017).
} 
(32): 161-184.

Ciencia e Investigación. 1950. La divulgación de la ciencia, 6(1): 1-2.

1951. El Consejo Nacional de Investigaciones, 7(8): 337-339.

1953a. Las Academias, 9(1): 1-2.

1953b. Editorial, 9(12): 529-531.

CONICET. 21-12-1962. Acta de la 109a reunión de directorio. Archivo Conicet, Dirección de Control Legal y Técnico.

Cueto, Marcos. 1994a. Laboratory Styles in Argentine Physiology. Isis 85(2): 228-246.

Cueto, Marcos. 1994b. The Rockefeller Foundation's medical policy and scientific research in Latin America. The case of physiology. In Missionaries of science. The Rockefeller Foundation in Latin America, ed. Marcos Cueto, 126-148. Bloomington and Indiana: Indiana University Press.

Dagnino, Renato, and Hernán Thomas. 1999. Latin American Science and Technology Policy: New Scenarios and the Research Community. Science, Technology and Society 4(1): 35-54.

DNICyT. n.d. Segundo Plan Quinquenal. Objetivo VI.G.4. Conducción Nacional de las Investigaciones Científicas y Técnicas. Carta Orgánica. Buenos Aires: Dirección Nacional de las Investigaciones Científicas y Técnicas.

Edgerton, David. 2004. 'The linear model' did not exist: Reflections on the history and historiography of science and research in industry in the twentieth century. In The Science-Industry Nexus: History, Policy, Implications, eds. Karl Grandin and Nina Wormbs. New York: Watson.

Elzinga, Aant, and Andrew Jamison. 1996. El cambio de las agendas políticas en ciencia y tecnología. Zona Abierta 75/76: 91-132.

Feld, Adriana. 2015. Ciencia y politica(s) en la Argentina: 1943-1983. Bernal: Universidad Nacional de Quilmes.

Finnemore, Martha. 1993. International organizations as teachers of norms: The United Nations Educational, Scientific, and Cultural Organization and science policy. International Organization 47(4): 565-597.

Ford Foundation. 1966. El Programa de la Fundación Ford en la Argentina, Archivo CONICET, Carpeta Fundación Ford.

Freeman, Christopher. 1982. The economics of industrial innovation, $2^{\text {nd }}$ edn. London: Pinter. Frondizi, Arturo. 1958. Plan de Reactivación Científica (pamphlet).

Frondizi, Risieri. 2001 [1956]. La Universidad y sus misiones. In La batalla de las ideas (1943-1973), comp. Beatriz Sarlo. Buenos Aires: Ariel.

1958 [1957]. Hacia la Universidad Nueva. Resistencia: Departamento de Extensión Universitaria y Ampliación de Estudios de la Universidad Nacional del Nordeste.

Galison, Peter, and Bruce Hevly (eds.). 1992. Big Science: The Growth of Large-Scale Research. Stanford: Stanford University Press.

García, Rolando V. 1963. El desarrollo científico y el progreso del país. Conferencia pronunciada en la Facultad de Ciencias Médicas de la Universidad de Buenos Aires, August 1963, Archivo de la Biblioteca Nacional, Fondo Documental Centro de Estudios Nacionales Arturo Frondizi, Sub-fondo Centro de Estudios Nacionales, Legajo 1415.B.12.5.2.

1966. Organizing Scientific Research. Bulletin of the Atomic Scientists 22(7): 12-15.

1971. Universidad y frustración. Entrevista a Rolando V. García, Ciencia Nueva, Year II, Issue 13: 18-21.

2003. La construcción de lo posible. In La construcción de lo posible: la Universidad de Buenos Aires 1955-1966, eds. Catalina Rotunno and Eduardo Díaz de Gujarro, 43-70. Buenos Aires: Libros del Zorzal. 
Gieryn, Thomas F. 1983. Boundary-Work and the Demarcation of Science from NonScience: Strains and Interests in Professional Ideologies of Scientists. American Sociological Review 48(6): 781-795.

Giudici, Ernesto. 1959. Problemas ideológicos científicos, técnicos y filosóficos en la Universidad. Buenos Aires: Fundamentos.

Glondys, Olga. 2018. Dismissals of the Congress for Cultural Freedom's representatives in Latin America as part of the strategy of 'Opening to the Left' (1961-1964). Culture \& History Digital Journal 7(1): e010. https://doi.org/10.3989/chdj.2018.010

Godin, Benoît. 2009. The Making of Science, Technology and Innovation Policy: Conceptual Frameworks as Narratives, 1945-2005. Montreal: Centre-Urbanization Culture Société, Institut National de la Recherche Scientifique.

Grandin, Greg. 2002. Off the Beach: The United States, Latin America, and the Cold War. In A Companion to Post-1945 America, eds. Jean-Christophe Agnew and Roy Rosenzweig. Oxford: Blackwell Publishers.

Herrera, Amílcar. 1973. Los determinantes sociales de la política en América Latina. Política científica explícita y política científica implícita. Desarrollo Económico 13(49): 113-134.

Heyck, Hunter, and David Kaiser. 2010. Introduction: New perspectives on science and the Cold War. Isis 101(2): 362-366.

Houssay, Bernardo. 1989 [1942]. La investigación científica. In Escritos y Discursos del Bernardo A. Houssay, comps. Ariel Barrios Medina and Alejandro C. Paladini, 302-322. Buenos Aires: Eudeba.

1989 [1946]. La ciencia necesita un ambiente de libertad. In Escritos y Discursos del Bernardo A. Houssay, comps. Ariel Barrios Medina and Alejandro C. Paladini, 326-327. Buenos Aires: Eudeba.

1989. [1954], La libertad académica y la investigación científica en la América Latina. In Escritos y Discursos del Bernardo A. Houssay, comps. Ariel Barrios Medina and Alejandro C. Paladini, 328-347. Buenos Aires: Eudeba.

Hurtado de Mendoza, Diego, and Analía Busala. 2002a. La divulgación como estrategia de la comunidad científica: la revista Ciencia e Investigación (1945-1948). Redes 9(18): 3362.

2002b. Los ideales de universidad 'científica' 1931-1959. Buenos Aires: Libros del Rojas.

2006. De la 'movilización industrial' a la 'Argentina científica': la organización de la ciencia durante el peronismo (1946-1955). Revista da Sociedade Brasileira de História da Ciência 4 (1): 17-33.

Hurtado de Mendoza, Diego, and Adriana Feld. 2010. La revista Mundo Atómico y la 'nueva Argentina científica'. In Ideas y debates para la Nueva Argentina. Revistas culturales y políticas del peronismo, comps. Claudia Panella and Guillermo Korn, 199-228. La Plata: Ediciones EPC-Facultad de Periodismo UN La Plata.

Huxley, Julian. 1950. Libertad para la Ciencia: un llamado a la acción. Ciencia e Investigación, VI (3): 131-132.

Iber, Patrick. 2015. Neither Peace nor Freedom: The Cultural Cold War in Latin America. Cambridge: Harvard University Press.

Joseph, Gilbert M. 2008. What We Now Know and Should Know: Bringing Latin America More Meaningfully into Cold War Studies. In In from the Cold: Latin America's New Encounter with the Cold War, eds. Gilbert M. Joseph and Daniela Spenser, 3-46. Durham: Duke University Press

Kaldewey, David, and Désirée Schauz. 2017. 'The Politics of Pure Science' Revisited. Science and Public Policy 44(6): 883-886.

Kleinman, Daniel Lee, and Mark Solovey. 1995. Hot science/Cold War: The National 
Science Foundation after World War II. Radical History Review 63: 111-139.

Kline, Ronald. 1995. Construing 'Technology' as 'Applied Science': Public Rhetoric of Scientists and Engineers in the United States, 1880-1945. Isis 86(2): 194-221.

Knorr-Cetina, Karin D. 1982. Scientific communities and transepistemic arenas of research? A critique of quasi-economic models of science. Social Studies of Science 12(1): 101130.

Kreimer, Pablo. 2006. ¿Dependientes o integrados? La ciencia latinoamericana y la división internacional del trabajo. Nómadas-Clacso 24: 196-213.

— 2010. Ciencia y Periferia. Nacimiento, muerte y resurrección de la biología molecular en la Argentina. Aspectos sociales, políticos y cognitivos. Buenos Aires: EUDEBA.

— and Hebe Vessuri. 2017. Latin American science, technology, and society: a historical and reflexive approach. Tapuya 1(1): 17-37.

Krige, John. 1999. The Ford Foundation, European Physics and the Cold War. Historical Studies in the Physical and Biological Sciences 29(2): 333-361.

Leavitt, Howard B. 1964. U.S. Technical Assistance to Latin American Education. Phi Delta Kappan 45(4): 220-225.

Leloir, Luis F. 1989 [1983]. Allá lejos y hace tiempo. Autobiografía Luis Federico Leloir. In Memorias del Instituto de Investigaciones Bioquímicas Fundación Campomar.

Levy, Daniel C. 2005. To Export Progress: The Golden Age of University Assistance in the Americas. Bloomington \& Indianapolis: Indiana University Press.

Mariscotti, Mario. 1985. El secreto atómico de Huemul. Buenos Aires: Sudamericana.

Mateos, Gisela, and Edna Suárez Díaz. 2012. Mexican science during the Cold War: an agenda for physics and the life sciences. Ludus Vitalis 20(37): 47-69.

Mayr, Otto. 1976. The Science-Technology Relationship as a Historiographic Problem. Technology and Culture 17(4): 663-673.

Merton, Robert K. 1992 [1942]. La ciencia y la estructura social democrática. In Teoría y estructura sociales, ed. Robert K. Merton, 636-647. Mexico City: Fondo de Cultura Económica.

Morris, Peter, and Anthony Travis. 2013. The Role of Physical Instrumentation in Structural Inorganic Chemistry. In Science in the Twentieth Century, eds. John Krige and Dominique Pestre, 715-740. London and New York: Routledge.

Mundo Atómico. 1950. Marchar sin vacilaciones. Un comentario a propósito de la creación de la Comisión Nacional de Energía Atómica, Year 1, Issue 2: 16-17.

Nállim, Jorge. 2006. Del antifascismo al antiperonismo: Argentina Libre, ...Antinazi y el surgimiento del antiperonismo político e intelectual. In Fascismo y antifascismo. Peronismo y antiperonismo. Conflictos políticos e ideológicos en la Argentina (19301955), ed. Marcela García Sebastiani, 77-105. Madrid, Iberoamericana/Vervuert

Nállim, Jorge A. 2014. Intelectuales y Guerra Fría: El Congreso por la Libertad de la Cultura en Argentina y Chile, 1950-1964. Anuario del Instituto de Historia Argentina, 14. http://www.memoria.fahce.unlp.edu.ar/art_revistas/pr.6730/pr.6730.pdf

Neiburg, Federico. 1988. Los intelectuales y la invención del peronismo. Madrid-Buenos Aires: Alianza Editorial.

Notes on Visit to Buenos Aires, Jul-Aug 1960. Box 3, Series III, FA612, Ford Foundation Records, Rockefeller Archive Centre.

Oreskes, Naomi. 2014. Introduction. In Science and Technology in the Global Cold War, eds. Naomi Oreskes and John Krige, 1-9. Cambridge, MA: MIT Press.

Oteiza, Enrique. 1992. El complejo científico y tecnológico argentino en la segunda mitad del siglo XX: la transferencia de modelos institucionales. In La política de investigación científica y tecnológica en la Argentina. Historia y perspectivas, dir. Enrique Oteiza, 115-125. Buenos Aires: Centro Editor de América Latina. 
Petra, Adriana. 2013. Cultura comunista y Guerra Fría: los intelectuales y el Movimiento por la Paz en la Argentina. Cuadernos de Historia 38: 99-130.

Pielke Jr., Roger A. 2012. Basic Research as a Political Symbol. Minerva 50(3): 339-361.

Plotkin, Mariano Ben. 2007. Mañana es San Perón. Propaganda, rituales políticos y educación en el régimen peronista, 1946-1955. Buenos Aires: EDUNTREF.

Polanyi, Michael. 1962. The Republic of Science: Its Political and Economic Theory. Minerva 1: 54-73.

Price, Derek J. de Solla. 1963. Little science, big science. Columbia University Press: Nueva York.

Rabkin, Yacob. 1987. Technological Innovation in Science: The adoption of Infrared Spectroscopy by Chemists. Isis 78: 31-54.

Registro Científico Nacional. 1955. Reseña General, Buenos Aires.

Romero, Luis A. 1994. Breve Historia Contemporánea de la Argentina. Buenos Aires: Fondo de Cultura Económica.

Sagasti, Francisco. 2011. Ciencia, Tecnología, Innovación. Políticas para América Latina. Lima: Fondo de Cultura Económica.

Salomon, Jean- Jacques. 1984. What is technology? The issue of its origins and definitions. History and Technology: An International Journal 1:2, 113-156.

Sarlo, Beatriz. 2001. La batalla de las ideas. 1943-1973. Buenos Aires: Ariel.

Schatzberg, E. 2006. Technik comes to America: changing meanings of technology before 1930. Technology and Culture 47(3): 486-512.

Schauz, Désirée. 2014. What is Basic Research? Insights from Historical Semantics. Minerva 52(3): 273-328.

Scott-Smith, Giles, and Charlotte A. Lerg. 2017. Introduction: Journals of Freedom? In Campaigning culture and the global Cold War: the journals of the Congress for Cultural Freedom, eds. Giles Scott-Smith and Charlotte A. Lerg, 1-24, London: Palgrave Macmillan.

Shils, Edward. 1954. The Scientific Community: Thought after Hamburg. Bulletin of the Atomic Scientist 10(5): 151-155.

Sigal, Silvia. 2002. Intelectuales y poder en la década del sesenta. Buenos Aires: Siglo XXI.

Sikkink, Kathryn. 2009. El proyecto desarrollista en la Argentina y Brasil: Frondizi y Kubitschek. Buenos Aires: Siglo XXI.

Solovey, Mark. 2001. Introduction: Science and the State during the Cold War: Blurred Boundaries and a Contested Legacy. Social Studies of Science 31(2): 165-170.

Stonor Saunders, Frances. 1999. The Cultural Cold War: The CIA and the World of Arts and Letters. New York: The New Press.

Varsavsky, Oscar. 1969. Ciencia, política y cientificismo. Buenos Aires: Centro Editor de América Latina.

Van Dongen, Jeroen, Friso Hoeneveld, and Abel Streefland. 2015. Introduction. In Cold War Science and the Transatlantic Circulation of Knowledge, eds. Jeroen van Dongen, Friso Hoeneveld and Abel Streefland. Leiden: Brill.

Velho, Léa. 2005. S\&T Institutions in Latin America and the Caribbean: An Overview. Science and Public Policy, 32 (2): 95-108.

Vessuri, Hebe. 1996. La ciencia académica en América Latina en el siglo XX. Redes 1(2): 41-76.

Thorp, Rosemary. 1998. The Latin American economies, 1939-c.1950. In The Cambridge History of Latin America, vol. VI. Latin America since 1930: Economy and Society, ed. Leslie Bethell, 115-148. Cambridge: Cambridge University Press.

Wolf, Alfred, Reynold Carlson, Lincoln Gordon, and Kalman Silvert. 1959. Exploratory Mission to Latin America. Report no. 131, Box 3, Series III, FA612, Ford Foundation 
Records, Rockefeller Archive Centre.

Wolfe, Audra. 2017. Science and freedom: The Forgotten Bulletin. In Campaigning Culture and the Global Cold War: The Journals of the Congress for Cultural Freedom, eds. Giles Scott-Smith and Charlotte A. Lerg, 27-43, London: Palgrave Macmillan. 
Response to reviewer's comments

Dear Editor,

The manuscript has already been revised by a native English speaker.

Kind regards,

Adriana Feld 